\title{
SHOULD ETHIGAL AND LEGAL STANDARDS FOR PHYSICIANS BE GHANGED TO ACCOMMODATE NEW MODELS FOR RATIONING HEALTH CARE?
}

\author{
EDWARD B. HIRSHFELD $\dagger$
}

\section{INTRODUCTION}

This Commentary provides a physician-oriented perspective on rationing health care. ${ }^{1}$ It frames the rationing issues that are facing physicians and suggests ways in which they should be handled.

Americans expect that all people should have access to health care when it is necessary for the diagnosis or treatment of an illness or injury. ${ }^{2}$ This ideal is based on our perception that health care can be essential to the maintenance of life itself, and may also be

† Associate General Counsel, American Medical Association. The author acknowledges and is grateful for the substantial efforts of Karen P. O'Neill, Legal Assistant, Sidley \& Austin, and Susan M. Browning, MPH, Senior Policy Analyst, American Medical Association, in the preparation of this Commentary.

1 For purposes of this Commentary, rationing is defined as making a choice among the claims of individuals who are competing for scarce resources. This broad definition includes implicit rationing, which occurs in distribution methods that do not involve a declared intent to ration pursuant to a predetermined plan, but which may result in denials of goods or services to some individuals. See generally David M. Eddy, Rationing by Patient Choice, 265 JAMA 105, 106 (1991) (presenting an analysis of implicit rationing, which is referred to as "patient-choice rationing," and comparisons to other methods of rationing, such as "top-down" and "meat-ax" rationing); David C. Hadorn \& Robert H. Brook, The Health Care Resource Allocation Debate: Defining our Terms, 266 JAMA 3328, 3331 (1991) (defining rationing as the "societal toleration of inequitable access . . . to services deemed necessary, as defined by reference to appropriate clinical guidelines"). The definition also includes explicit rationing, where individual rationing decisions are deliberately and systematically made pursuant to a predetermined set of criteria. An example of explicit rationing is the evaluations done by committees that review candidates for transplant surgery when the supply of available organs falls short of demand. The candidates are evaluated pursuant to predetermined criteria to decide who should receive the organ transplant. Cf., e.g., Basil A. Stoll, Choosing Between Cancer Patients, 16 J. MED. ETHICS 71 (1990) (discussing the selection of patients for cancer treatment using criteria/ guidelines); see also P.A. Lewis \& M. Charney, Which of Two Individuals Do You Treat When Only Their Ages Are Different and You Can't Treat Both?, 15 J. MED. ETHICs 28, 2932 (1989) (analyzing the Cardiff Health Survey which utilized public opinion surveys to determine criteria for medical treatment).

${ }^{2}$ See David Mechanic, Future IsSUes in Health CARE 38-47 (1979). 
essential for the enjoyment of life free from disability. Health policy in the United States has long been oriented towards assuring that all Americans have access to needed health care, and enormous progress has been made during the past fifty years to achieve that goal. ${ }^{3}$ It has not, however, been attained. Implicit, market-based rationing ${ }^{4}$ has always existed in the United States and continues to affect a substantial number of Americans. While about $85 \%$ of the population is covered by a health plan that finances needed health

${ }^{3}$ For at least the past fifty years, the dominant theme in public policy for health care has been to eliminate rationing. That theme has resulted in legislation to facilitate the creation of not-for-profit, privately organized health plans, such as those sponsored by the Blue Cross and Blue Shield Associations, see ROBERT D. EILERs, REgUlatToN OF BLUE CROSS AND BLUE SHIELd PlaNS 104-09 (1963), the development of federal and state programs to finance hospital construction, see Hospital Survey \& Construction Act of 1946, Pub. L. No. 79-725, 60 Stat. 1041 (1946) (current version at 42 U.S.C. $\$ \S 291$ to 2910-1 (1988)), the funding for education of health care professionals, see Comprehensive Health Manpower Training Act of 1971, Pub. L. No. 92-157, 85 Stat. 431 (1971) (codified as amended at 42 U.S.C. $\$ \$ 292 \mathrm{a}$ to $295 \mathrm{~g}-11$ (1988)), and the passage of the federal Medicare programs to cover elderly and disabled individuals and the federal and state Medicaid program to cover the impoverished, see The Social Security Amendments of 1965, Pub. L. No. 89-97, 79 Stat. 286 (Medicare provisions codified as amended at 42 U.S.C. $\$ \S 1395-1395 \mathrm{ccc}$; Medicaid provisions codified as amended at 42 U.S.C. $\$ \S 1396-1396$ s (1988 \& Supp. I 1989)).

We subsidize the individual by creating pools of funds that can be accessed when health care is needed. These pools, which we call health insurance or health plans, are privately organized by employers, associations, and other interest groups, and by health insurers for individuals not affiliated with one of these groups. See CONGRESSIONAL BUDGET OFFICE, SELECTED OPTIONS FOR EXPANDING HEALTH INSURANCE COVERAGE-\#2, at 3 (1991) [hereinafter SELECTED OPTIONS].

These pools insulate most individuals from being deprived of health care due to a lack of resources to compete for services in a true market. See CoNGrEsSIONAL Budget Office, Rising Health CARE Costs: Causes, Implications, and STRATEgIes 26 (1991) [hereinafter RISING HEALTH CARE COSTS]. Beneficiaries of a pool generally may consume as many services as are deemed medically necessary within the limits of coverage provided by the pool. Standardized health insurance policies, as well as Medicare coverage, provide reimbursement for medical treatment and services that are "reasonable and necessary for the diagnosis or treatment of an illness or injury," provided that the services or products used are "safe and effective" and not merely "experimental." 42 U.S.C. $\$ 1395 y(a)(1)(A)(1988)$.

4 A market is a form of implicit rationing. See PAUL A. SAMUELSON \& WILLIAM D. NORDHAUS, ECONOMICS 69 (12th ed. 1985). All individuals are equally eligible to purchase any medical service in a market for health care, and there is no intent to deny services to any individual. Purchasers unwilling or unable to pay market prices for goods do not obtain them, however. Queuing is another form of implicit rationing. See Henry A. Shenkin, Clinical PRACTICE ANd Cost Containment 58-62 (1986); Uwe E. Reinhardt, Rationing the Nation's Health-Care Surplus: An American Paradox, THE INTERNIST, Feb. 1986, at 11, 11. Anyone may enter a queue for health care services, but care may be delayed until it is too late to be beneficial. 
care, there are thirty-four to forty million individuals who are not covered by a health plan. ${ }^{5}$ In addition, of those Americans who are covered by a health plan, it is estimated that twenty million are underinsured, meaning that they do not have adequate coverage. ${ }^{6}$

${ }^{5}$ A substantial number of people, recently estimated at $33,400,000$, are not covered by a pool. See RISING HEALTH CARE CosTs, supra note 3, at 67 . An additional large share of the population, which one estimate places at $20,000,000$, see LEWIN/ICF, HEALTH \& SCIENCES INT'L, THE HEALTH CARE FINANCING SYSTEM AND THE UNINSURED 26 (1989) [hereinafter HEALTH CARE FINANCING SYSTEM], is underinsured, meaning that they have some coverage from a pool but still bear a material risk of paying substantial amounts for health care services.

Many uninsured persons do not qualify for entry into a privately organized pool or a government program and cannot afford to purchase their own health plan. These people are at risk of not being able to obtain needed health care due to implicit rationing, and they do not have the means to avoid the risk. They include, for example, low-income individuals (and their dependents) whose employers do not provide a health plan, but who are not sufficiently impoverished or old enough to qualify for a government plan. See id. at xi; see also SELECTED OPTIONS, supra note 3, at 12 (analyzing why individuals are uninsured); HEALTH CARE FINANCING SYSTEM, supra, at 7 (discussing characteristics of uninsured populations); Emily Friedman, The Uninsured: From Dilemma to Crisis, 265 JAMA 2491, 2491-92 (1991) (same). Also included are the unemployed and their dependents who, although impoverished, do not meet various eligibility requirements of a government program. An increasing number of uninsured would ordinarily be covered by an employer sponsored health plan, but are not accepted because they have substantial medical problems, which presents a larger potential liability than the employer or its insurer wants to accept. See Long-Term Strategies for Health Care: Hearings Before the House Comm. on Ways and Means, 102d Cong., 1st Sess. 3 (1991) (statement of Robert D. Reishauer, Director, Congressional Budget Office); RISING HEALTH CARE COSTS, supra note 3, at 70-71.

There are uninsured who apparently have access to a plan, but do not participate. The reasons why are not well understood. Some have access to an employer-sponsored health plan, but refuse it because the employer requires participants to pay part of the cost of the plan. These people may be unable or unwilling to bear the cost sharing. In addition, there is a substantial number of uninsured people who do not qualify for an employer-sponsored plan, but appear to have enough income to purchase their own health plan. Finally, a substantial group of uninsured are eligible for the federal and state sponsored Medicaid program but do not enroll, perhaps because of lack of information or sophistication. See HEALTH CARE FINANCING SYSTEM, supra, at 107-09. While some of the uninsured may choose to bear the risk of no coverage, most do not have a choice. For an illustration and debate of the equality of access to health care, see Amy Gutmann, For and Against Equal Access to Health Care, in IN SEARCH OF EQUITY: HEALTH NEEDS AND THE HEALTH CARE SYSTEM 43 (Ronald Bayer et al. eds., 1983).

${ }^{6}$ The underinsured are individuals who are included in a health plan, but who might not be able to obtain needed care under the terms of the plan. Some plans, especially government plans, are underfunded and do not pay providers enough to allow their beneficiaries to compete for services with the beneficiaries of betterfunded plans. See HEALTH CARE FINANCING SYSTEM, supra note 5, at 70-71. Other underinsured individuals have health problems that are not covered by their plans. See id. at 24. Still others may have consumed so much health care that they have exhausted the financial limits of the terms of coverage under the plan. And some 
During recent years, our progress towards attaining the ideal of $100 \%$ access to needed health care has been threatened by rapidly increasing expenditures on health care. ${ }^{7}$ The increases are straining the ability of payers to maintain existing levels of coverage and are hampering the effort to expand coverage for the uninsured. $^{8}$ As a result, there is great concern that the United States

may need care which is excluded from the plan, such as medical services considered to be experimental.

7 The expenditure problem is well documented. The total amount spent on health care in the United States increased from $\$ 249$ billion in 1980 to $\$ 604$ billion in 1989. See Prospective Payment Assessment Comm'n, Medicare and the AMERICAN Health CARE System 11 (1991) [hereinafter Payment Assessment COMM'N]. After adjusting for inflation, the real annual rate of growth in total health care spending from 1980 to 1989 was $5.4 \%$. See id. In terms of 1989 dollars, real health care spending per capita rose from $\$ 950$ in 1970 to $\$ 2354$ in 1989 , an average annual growth rate of about $4.9 \%$. See RISING HEALTH CARE COSTS, supra note 3, at 2. By comparison, real rates of growth for other sectors of the economy during the same years (1970-1988) were much smaller. Spending for food increased at an average annual rate of about $1 \%$, and spending for housing increased at an average annual rate of $3 \%$. See CoNGressional BUDGeT OfFICE, TRENDS IN HEALTH EXPENDITURES BY MEDICARE AND THE NATION 5 (1991) [hereinafter TRENDS IN HEALTH EXPENDITURES].

As a result of its growth rate, health care spending accounts for an increasing share of the gross national product (GNP). The percentage of GNP attributed to health care increased from $9.1 \%$ in 1980 to $11.6 \%$ in 1989. See Katharine R. Levit et al., National Health Care Spending, 1989, Health AFF., Spring 1991, at 117, 119 exhibit 2. Government officials estimate that if current growth rates in health care spending continue, health care will account for $15 \%$ to $16 \%$ of GNP by the year 2000 . See TRENDS IN Health EXPENDITURES, supra, at 8; Sally T. Sonnefeld et al., Projections of National Health Expenditures Through the Year 2000, 13 HEALTH CARE FIN. REv. 1, 1 (1991). Although the service sector, which includes health care services, expanded as a percentage of GNP throughout the $1980 \mathrm{~s}$, health care services increased at twice the rate of all other services. See PAYMENT ASSESSMENT COMM'N, supra, at 12.

${ }^{8}$ The increasing expenditure on health care services during recent years threatens to outstrip the ability of health plans to pay for care needed by their beneficiaries. The cost of maintaining private plans is rising. See Tim Healy, High Stakes-For the SelfInsured-Health Costs Push Small Employers to Seek Alternatives, SEATTLE TIMES, Feb. 4, 1991, at B1; Paul J. Kenkel, Indemnity Plans Rate Higher in Worker Satisfaction, MODERN HEALTHCARE, Feb. 17, 1992, at 44, 44; David Zinman, The National Insurance Campaign, NEWSDAY, June 5, 1990, at 5. And tax revenues are not increasing fast enough to replenish the government plans. See Sonnefeld et al., supra note 7, at 1 . Due to the measures taken by private and government plans to control costs, more people are losing some or all of their health care coverage.

Employers are starting to demand that employees contribute more towards the cost of health plans, which causes more employees to terminate their coverage because they feel they cannot afford to participate. See HeALTH CARE FINANCING SYSTEM, supra note 5, at 98; see also Healy, supra, at B1 (discussing problems faced by employees of employer self-funded insurance plans); William Raspberry, Health Care For Everyone, WASH. POST, Feb. 23, 1990, at A23 (commenting on the high degree of employee concern over the increased cost of health care). The employees who do 
will lose many of the gains already made as a result of efforts to attain the ideal, unless solutions to the cost problem are found and implemented. ${ }^{9}$ The reasons for the cost problem are numerous, but they can be organized into two categories: (1) inefficiencies in the finance and delivery of health care, and (2) fundamental factors that could not be altered by eliminating inefficiencies. Two types of solutions have been proposed to resolve the problem of increasing costs-one optimistic and the other pessimistic.

participate are aware of the greater risk of incurring medical expenses, as cost sharing mechanisms such as co-payments and deductibles increase. See HEALTH CARE FINANCING SYSTEM, supra note 5, at 98 . Some employers are reducing the scope of coverage; they have dropped coverage for prescription drugs and limited the extent of coverage for expensive services such as mental health care. See Mark Merenda, Business and Abuse: The Mental Health Mess, FLA. BuS.-SouTHWEST, Oct. 1990, at 14, available in LEXIS, Nexis Library, FBS File.

Employers are also reducing coverage limits, which increases the likelihood that an employee will run out of coverage in the event of a catastrophic health problem. See generally Health CARE Financing SYSTEM, supra note 5, at 32 (analyzing the consequences of underinsurance). Eligibility requirements for employer plans are becoming more restrictive. New employees increasingly are not being accepted into employer plans because of past health care problems, or they are being accepted subject to the exclusion of coverage for preexisting health problems. See id. at 95 . Finally, many small employers are dropping or not establishing health plans for their employees because they cannot afford the cost. See id. at 89.

${ }_{9}$ Numerous health care system reform proposals have been advanced in recent years for the purpose of eliminating implicit rationing. See generally Symposium, Caring For the Uninsured and Underinsured, 265 JAMA 2491 (1991) (presenting numerous health care reform proposals concerning Medicaid, health care access, employer insurance, and Medicare). The proposals have been advanced by academicians, think tanks, health care industry trade associations, general business trade associations, politicians, and others. Many of them have been converted into legislative bills that are pending in Congress and state legislatures. See Laura E. Noble, Healthcare Reform Stews in Congressional Pressure Cooker, HEALTHCARE FIN. MGMT., Jan. 1992, at 21, 28-36 (presenting an overview of three categories of healthcare reform bills: incremental approaches, employer-based programs, and single-payer programs). Several congressional bills aimed at reducing and eliminating inefficiencies of the health care system in order to control costs have recently been introduced. See AMERICAN MEd. Ass'N, HEALTH REForM Proposals of THE 102ND CoNGRESS AND THE PREsidentIAL CANDIDATES (1992) [hereinafter HEALTH REForM PROPOSALS] (providing analysis of numerous health care bills introduced in Congress); see also The President's CoMPREHENSIVE HeAlth Reform Program 31 (Presidential White Paper, released Feb. 6, 1992) [hereinafter PRESIDENT'S PROGRAM]; U.S. GEN. ACCOUNTING OfFICE, CANADIAN HEALTH INSURANCE: LeSSONS FOR THE UNITED STATES 28-71 (1991) [hereinafter CANADIAN HEALTH] (discussing Canadian singlepayer system and its applicability to the United States). For an overview of current state legislation, see Roger Thompson, States Take Lead in Health Reform, NATION's Bus., Apr. 1992, at 18. There is enough momentum behind the reform movement that it is widely expected that federal health reform legislation will be passed by Congress or by a number of states in the near future. 
The optimistic solution is to rein in costs and bring the economics of the health care system into balance by eliminating inefficiencies. ${ }^{10} \mathrm{~A}$ variety of health system dysfunctions would be targeted by these efforts, and numerous methods have been proposed to correct them, ranging from comprehensive government regulation to the introduction of controlled-market forces. A procedure that would be used by all the different proposals and that may be essential to the success of any is the development of criteria and techniques to distinguish needed care from unnecessary services. It is believed that one of the dysfunctions in our current system is the provision of substantial amounts of care that is not needed. ${ }^{11}$

The pessimistic solution assumes that elimination of inefficiencies will not solve the cost problem because fundamental factors-an aging population, advances in technology, and structural inflationwill continue to increase costs more rapidly than the underlying rate of inflation for the economy as a whole. ${ }^{12}$ Pessimists argue that rationing is the inevitable solution to cost increases, and they advocate that new models of rationing be developed. Some propose explicit rationing schemes under which health care would be allocated pursuant to equitable principles arrived at through an open and democratic process. ${ }^{13}$ Others advocate more sophisticat-

${ }^{10}$ See Alain C. Enthoven, Shattuck Lecture-Cutting Costs Without Cutting the Quality of Care, 298 NEW ENG. J. MED. 1229 (1978); see also Robert H. Brook \& Kathleen N. Lohr, Will We Need To Ration Effective Health Care?, IssuEs SCI. \& TECH., Fall 1986, at 68,68 (estimating that one-third of the nation's health care dollars go to unnecessary medical services and urging elimination of this problem by significantly altering the traditional concept of medical practice).

${ }^{11}$ See William B. Schwartz, The Inevitable Failure of Current Cost-Containment Strategies: Why They Can Provide Only Temporary Relief, 257 JAMA 220 (1987); Brook \& Lohr, supra note 10, at 72-73; see also John T. Kelly \& Shirley E. Kellie, Appropriateness of Medical Care: Findings, Strategies, 114 ARChIVES PATHOLOGY \& LABORATORY MED. 1119, 1119-20 (1990) (summarizing current literature concerning inappropriate medical services that questions whether a significant proportion (up to $20 \%$ ) of medical care is actually unnecessary, even though only $2 \%$ of claims reviewed by Medicare Peer Review Organizations were found unnecessary); Lucian L. Leape, Practice Guidelines and Standards: An Overview, 16 QUALITY REV. BULL. 42 (1990) (analyzing the use of practice guidelines as a tool to reduce inappropriate care and to help control costs); William L. Roper et al., Effectiveness In Health Care: An Initiative to Evaluate and Improve Medical Practice, 319 NEw ENG. J. MED. 1197, 1200 (1988) (reviewing patient outcome studies and the link to practice patterns).

12 See Schwartz, supra note 11, at 221.

13 See, e.g., John F. Kilner, Ethical Criteria in Patient Selection: Who LIVES? WHO DIES? (1990) (describing social, sociomedical, medical, and personal criteria that may be used in ethical rationing); Jennifer Dixon \& $\mathrm{H}$. Gilbert Welch, Priority Setting: Lessons from Oregon, 337 LANCET 891 (1991) (describing Oregon's 
ed versions of our existing system of implicit rationing. ${ }^{14}$

Some scholars have suggested that the standard of care in medical malpractice litigation be altered to accommodate explicit rationing or new forms of implicit rationing. ${ }^{15}$ The political reality, however, is that Americans generally do not want a comprehensive explicit rationing scheme or new forms of implicit rationing-they want access to needed health care. Therefore, the optimistic solution has been embraced by politicians and policy

rationing plan); David M. Eddy, What's Going on in Oregon?, 266 JAMA 417 (1991) (analyzing the impact of the Oregon rationing plan); $c f$. WARREN GREENBERG, Competition, Regulation, and Rationing in Health Care 139-49 (1991) (analyzing the effects of technology on rationing).

14 See, e.g., Richard A. Epstein, Medical Malpractice, Imperfect Information, and the Contractual Foundation for Medical Services, LAw \& CoNTEMP. ProBS., Spring 1986, at 201 (exploring influences on the expansion of medical malpractice liability and changes in the delivery of health care services); Clark C. Havighurst, Practice Guidelines For Medical Care: The Policy Rationale, 34 ST. LOUIS U. L.J. 777, 792 (1990) (discussing conceptual models for practice guidelines and policy purposes, and advocating that practice guidelines with different treatment approaches be available as the basis for health plan contracts); Maxwell J. Mehlman, Fiduciary Contracting: Limitations on Bargaining Between Patients and Health Care Providers, 51 U. PITT. L. REV. 365 (1990) (examining assumptions related to the use of patient-provider contracting); Glen O. Robinson, Rethinking the Allocation of Medical Malpractice Risks Between Patients and Providers, LAW \& CONTEMP. PROBS., Spring 1986, at 173 (analyzing the role of custom in the treatment of medical malpractice cases and the disadvantages of patient-provider contracting).

${ }^{15}$ See, e.g., Mark A. Hall, The Malpractice Standard under Health Care Cost Containment, 17 LAW MED. \& HEALTH CARE 347 (1989) (examining the views of commentators, particularly E. Haavi Morreim, on this issue). For commentators who, to accommodate rationing, advocate changing the standard of care for assessing malpractice claims, see Robert C. Macaulay, Jr., Health Care Cost Containment and Medical Malpractice: On a Collision Course, 21 SUFFOLK U. L. REV. 91, 103-07 (1986); E. Haavi Morreim, Cost Containment and the Standard of Medicare Care, 75 CAL. L. REv. 1719 (1987) [hereinafter Morreim, Cost Containment]; E. Haavi Morreim, Stratified Scarcity: Redefining the Standard of Care, 17 LAW MED. \& HEALTH CARE 356 (1989) [hereinafter Morreim, Scarcity]; Note, Rethinking Medical Malpractice Law in Light of Medicare Cost-Cutting, 98 HARV. L. REV. 1004, 1017-19 (1985); see also Jean Lairson, Reexamining the Physician's Duty of Care in Response to Medicare's Prospective Payment System, 62 WASH. L. REV. 791, 804 (1987) (arguing against modifying the standard of care to accommodate economic considerations); Diana Vance-Bryan, Note, Medicare's Prospective Payment System: Can Quality Care Survive?, 69 IowA L. REV. 1417 (1984) (arguing that malpractice laws will not be sufficient to protect patients from poor quality caused by consideration of economic factors). For commentators analyzing whether economic considerations will evolve into the standard of care as it is developed by the courts, see James F. Blumstein, Rationing Medical Resources: $A$ Constitutional, Legal, and Policy Analysis, 59 TEX. L. REV. 1345 (1981); Rand E. Rosenblatt, Rationing "Normal" Health Care: The Hidden Legal Issues, 59 TEX. L. REV. 1401 (1981); Peter H. Schuck, Malpractice Liability and the Rationing of Care, 59 TEX. L. REV. 1421 (1981). 
makers and efforts are being made to implement it. ${ }^{16}$ As a result, the problem that deserves our attention is not how to accommodate new forms of rationing; rather, it is how to define necessary as opposed to unneeded care. ${ }^{17}$

Under our current system, physicians and other providers make decisions about necessity in consultation with their patients, payers second guess those decisions, and courts may review the performance of providers and payers in malpractice or other tort litigation. Neither medicine nor law has a usable or reliable methodology or set of principles in place to distinguish between needed and unnecessary care, although one major theme followed is that the best interests of the patient should be the overriding concern when determining what care should be provided. ${ }^{18}$

${ }^{16}$ See supra note 9 and accompanying text.

17 The existing standard of care is actually compatible with existing forms of implicit rationing and would be compatible with explicit rationing. See infra parts IV.B \& V.

${ }^{18}$ The current legal standard of care for physicians is patient-interest oriented. It requires a physician to exercise the skill and care that a competent physician would apply in similar circumstances. See W. PAge KeEton ET AL., Prosser AND KeEton ON THE LAW OF TORTS $\$ 32$ (5th ed. 1984) [hereinafter Prosser ON TORTs]. In the process of exercising due care, the physician is to place the interests of the patient above all other considerations. See 61 AM. JUR. 2D Physicians, Surgeons, and Other Healers $§ \S 166-168$ (1981) [hereinafter PHYSICIANS, SURGEONS, AND OTHERs]. Ethical standards for physicians are similar. The AMA's Code of Medical Ethics states that a "physician has a duty to do all that he or she can for the benefit of the individual patient." COUNCIL ON ETHICAL AND Judicial AfFaIRS, AMERICAN MED. Ass'N, CODE OF MEDICAL ETHICS 3 op. 2.03 (1992) [hereinafter CODE OF MEDICAL ETHICs]; see also $i d$. at 20 op. 4.04 (stating that "where the economic interests of the hospital are in conflict with patient welfare, patient welfare takes priority"); id. at 7 op. 2.09 (" $[S]$ ocial policy expects that concern for the care the patient receives will be the physician's first consideration.").

Very similar patient-interest oriented standards of care apply to other health care professionals and to hospitals. Virtually all health care professionals are held to a standard of care that requires them to exercise the degree of skill and care that is applied by a competent individual of the same profession when treating patients. See PROSSER ON TORTS, supra, $\$ 32$, at 185 . Under the doctrine of respondeat superior hospitals are liable for the patient care provided by their employees, which usually include a wide variety of health care professionals. See generally Diane M. Janulis \& Alan D. Hornstein, Damned If You Do, Damned If You Don't: Hospitals' Liability for Physicians' Malpractice, 64 NEB. L. REV. 689 (1985) (presenting problems faced by hospitals held liable for physician's acts under the doctrine of respondeat superior). Under some conditions, hospitals are liable for professionals who have privileges to provide care at the hospital, but who are not employees, under theories of apparent or ostensible agency. See id. at 696-702; see also Claire G. Combs, Hospital Vicarious Liability for the Negligence of Independent Contractors and Staff Physicians: Criticisms of Ostensible Agency Doctrine in Ohio, 56 U. CIN. L. REV. 711 (1987) (providing analysis of the theory of ostensible agency, corporate negligence, and the doctrine of 


\section{Decisions about necessity, however, are based on case by case}

respondent superior). When a hospital is responsible for the patient care of health care professionals under these theories of vicarious liability, the standard of care applicable to the health care professional is also applied to the hospital. See Janulis \& Hornstein, supra, at 704-08.

A growing body of law is beginning to apply theories of vicarious liability to payers, especially to HMOs and PPOs that limit a patient's choice of providers to those who have contracted to provide care to their beneficiaries. Like hospitals, these payers are held to the standard of care applicable to the provider involved under theories of vicarious liability. See Bush v. Dake, No. 86-25767NM (Cir. Ct. Saginaw County, Mich. Apr. 27, 1986); Harrell v. Total Health Care, Inc., No. WD 39809, 1989 Mo. App. LEXIS 577 (Mo. Ct. App. Apr. 25, 1989), overruled on other grounds by 781 S.W.2d 58 (Mo. 1989) (en banc); DeGenova v. Ansel, 555 A.2d 147 (Pa. Super. Ct. 1988); Boyd v. Albert Einstein Medical Ctr., 547 A.2d 1229 (Pa. Super. Ct. 1988); see also Schleier v. Kaiser Found. Health Plan, 876 F.2d 174, 177-78 (D.C. Cir. 1989) (holding HMO vicariously liable for negligence of consulting physician); Sloan v. Metropolitan Health Council, Inc., 516 N.E.2d 1104, 1108-09 (Ind. Ct. App. 1987) (holding that HMOs can be liable for physician/employee conduct under the doctrine of respondeat superior); Williams v. Good Health Plus, Inc., 743 S.W.2d 373, 374-77 (Tex. Ct. App. 1987) (holding HMO not liable for physicians found to be independent contractors); Randall Bovbjerg, The Medical Malpractice Standard of Care: HMOs and Customary Practice, 1975 DUKE L.J. 1375 (presenting problems and solutions surrounding the application of malpractice law to HMOs); William J. Curran \& George B. Moseley, III, The Malpractice Experience of Health Maintenance Organizations, 70 Nw. U. L. REV. 69 (1975) (examining HMO malpractice claim activity); Mark S. Joffe, Potential HMO and Physician Liability Arising From Physician Incentive Arrangements, HEAlTHSPAN, Dec. 1988, at 9 (discussing HMOs' use of physician incentives aimed at reducing unnecessary care in relation to their potential liability). In addition, there are cases that appear to extend liability to payers that make decisions about whether to pay for care recommended by physicians before the services are provided, a process known as prospective or concurrent utilization review. Since the grounds for refusing coverage may be lack of medical necessity for the services, and since the services are generally not provided when coverage is denied, payers may be liable for coverage denials based on erroneous conclusions that the services are not necessary. The standard of care applicable to utilization review decisions of payers appears to be similar to the standard of care applicable to the health care professionals who recommend the care for which coverage is requested. See Wilson v. Blue Cross, 271 Cal. Rptr. 876 (Cal. Ct. App. 1990); Wickline v. California, 239 Cal. Rptr. 810 (Cal. Ct. App. 1987); see also Sondra J. Byrnes, Corporation's Institution of Health Care Review: Legal Risks, 33 MED. TRIAL TECH. Q.478, 480 (1987) (discussing the legal implications of utilization review programs); William A. Helvestine, Legal Implications of Utilization Review, in CoNTROLling CosTs AND ChangIng PATIENT CARE? ThE Role of Utilization MANAGEMENT 169 app. A (1989) (reviewing existing legal guidelines surrounding utilization review decisions); Rand E. Rosenblatt, Redefining Administrative Liability, 12 HEALTH MGMT. Q. 9 (1990) (commenting on the emergence and growth of "administrative malpractice"); Ronald P. Smith, Insurance Carrier Liability as a Result of Pre-Admission Screening and Hospital Stay Guidelines, 12 OHIO N.U. L. REV. 189 (1985) (analyzing malpractice liability of insurance carriers requiring utilization reviews); Kevin $R$. Jespersen \& George $H$. Kendall, Utilization Review: Avoiding Liability While Controlling Costs, HEALTHSPAN, July 1987, at 3 (1987) (discussing the sources and theories of liability related to utilization reviews and presenting steps to avoid such liability). 
determinations aided by the judgments of medical professionals as opposed to the application of a set of predetermined criteria. ${ }^{19}$

Currently, physicians and others are attempting to develop criteria for the identification of unnecessary care. ${ }^{20}$ The issue is important because where the boundary is set defines the difference between the withholding of unneeded care and the failure to provide or recommend needed services (i.e. malpractice). Ultimately, the boundary defines the difference between rationing and withholding of unnecessary care. One of the primary issues involved in defining necessary care is the extent to which the societal interest in conserving costs should be taken into account. While economic considerations have not been totally excluded by physicians and courts in decisions about what care should be provided to a patient, such considerations have not played a major role. In deliberations about the extent to which the societal interest should be taken into account, it may be possible to redefine-as the provision of unnecessary care-the withholding of certain types of care that providers and courts would now consider to be rationing.

Physicians will play an important role in the process of defining what constitutes unnecessary care. They will provide the medical information necessary to form opinions about whether care should be provided in certain situations, and they will also develop and advocate their own opinions about necessity. This Commentary argues that physicians should adhere to traditional patient-interest oriented ethical and legal standards when developing medical information and forming opinions about necessity. Other societal institutions, including legislatures, regulatory agencies, and courts, may choose to override physician opinions about necessity and give greater weight to the societal interest in conserving costs. Given

19 See CODE OF MEdical ETHICs, supra note 18, at 3 op. 2.03.

${ }^{20}$ See supra note 11 and accompanying text. Some commentators point out that physician organizations and others have been developing guidelines for many years, but they also recognize that the scale and scope of current efforts is new and unprecedented. See U.S. Gen. Accounting OfFICE, Practice Guidelines: ThE EXPERIENCE of MEdical SPECIALTy Societies 1 (1991); Anne-Marie Audet et al., Medical Practice Guidelines: Current Activities and Future Directions: 113 ANNALS INTERNAL MED. 709 (1990); Mark R. Chassin, Standards of Care in Medicine, 25 INQUIRY 437, $437-38$ (1988); John T. Kelly \& James E. Swartwout, Development of Practice Parameters by Physician Organizations, 16 QUALTTY REV. BULL. 54 (1990); Eleanor D. Kinney \& Marilyn M. Wilder, Medical Standard Setting in the Current Malpractice Environment: Problems and Possibilities, 22 U.C. DAVIS L. REV. 421 (1989); Steven H. Woolf, Practice Guidelines: A New Reality in Medicine, 150 ARCHIVES INTERNAL MED. 1811 (1990). 
that these institutions have the ability to do so, and given that they are ultimately accountable to the populace in a representative democracy, it is appropriately their role to make such decisions and there is no reason for physicians to abandon their traditional role as the patient's advocate. If that role is abandoned, we lose something of incalculable value.

\section{Causes of Rising Costs}

The debate over how to control costs is crucial to the issue of whether rationing can be eliminated. There are two basic reasons for cost increases: rising prices for health care services and increases in the volume and intensity of services. ${ }^{21}$ The problems are interrelated in cause and effect. It is not enough to bring one problem under control without the other. Increases in prices can offset savings achieved by reducing volume, and volume increases can obliterate savings achieved by reducing prices. Of these two problems, however, the more difficult one is controlling volume and intensity. Prices can be limited by government price control regulations or the introduction of market forces. The Gordian knot is whether volume can be controlled without denying people needed care.

As was mentioned earlier, many observers believe that it is possible to bring volume and intensity under control without denying anyone needed health care; others disagree. ${ }^{22}$ To understand the differences in these perspectives, it is necessary to examine the perceived causes of health care cost increases. There appear to be multiple causes, but the extent to which each cause contributes to cost increases is not known. Some of the problems are external to the health care system, which means that the problems cannot be eliminated by altering health policy. Other problems exist within the health care system and therefore can be more easily resolved. The major factors thought to contribute to increases in volume and intensity are discussed below.

21 See Henry Aaron \& William B. Schwartz, Rationing Health Care: The Choice Before Us, 247 SCIENCE 418, 418 (1990); Eddy, supra note 1, at 105.

22 See supra notes 10-12 and accompanying text. Compare Enthoven, supra note 10, at 1229-30, 1234-37 (arguing that a system where consumers and providers participate in resource controlled plans will result in a decrease in costs) with Schwartz, supra note 11, at 220-24 (arguing that reducing unnecessary care decreases expenditures, but has little or no real impact on rising costs). 


\section{A. Factors Internal to the Health Care System ${ }^{23}$}

\section{Health Insurance and Government Health Plans}

Perhaps the most significant contributor to increased health care expenditures is the spread of private health insurance programs and the creation of Medicare, Medicaid, and other government health plans. Employer sponsored health insurance and subsidized government plans insulate patients from the price of health care. ${ }^{24}$ Historically, the existence of health insurance and government plans also insulated providers from their own costs. Insurers and health plans generally paid for medical care on the basis of "usual, customary, and reasonable" fees and charges. ${ }^{25}$ Some insurers simply paid the usual and customary fees or charges of providers,

${ }^{23}$ In addition to the factors discussed in this Section, two other major inefficiencies that inflate prices are increased regulation and administrative costs. Massive increases of government regulation of the health care industry contribute to rising costs. For example, in 1992 alone, the implementation of just three regulatory schemes will increase physician's costs by hundreds of millions of dollars. These new schemes are: (1) regulations designed to protect health care workers from bloodborne pathogens, see Occupational Exposure to Bloodborne Pathogens, 56 Fed. Reg. 64,004 (1991) (to be codified at 29 C.F.R. $\$ 1910.1030$ ), (2) regulations designed to assure the quality of laboratories maintained in physician offices, promulgated under the Clinical Laboratory Improvement Amendments of 1988, Pub. L. No. 100-578, 102 Stat. 2903 (codified at 42 U.S.C \$ 263a (1988)), and (3) regulations designed to make physician offices more accessible to disabled patients, promulgated under the Americans with Disabilities Act of 1990, Pub. L. No. 101-336, 104 Stat. 327 (codified at 42 U.S.C.A. \$\$12101-12213 (West Pamphlet 1992)). OSHA estirnates that compliance with the blood-borne pathogens regulations will cost physicians a minimum of $\$ 144$ million annually. See Occupational Exposure to Bloodborne Pathogens, 56 Fed. Reg. at 64,039.

The administrative costs of the health care system are estimated to consume $20 \%$ of total expenditures. Part of this is attributable to government regulations, the rest is attributable to the existence of numerous payers. Providers have to keep track of the claims, procedures, and criteria of numerous different entities. It is believed that administrative costs would be much lower if providers had only one set of claims procedures and criteria to comply with. See CANADIAN HEALTH, supra note 9, 28-33, 40-42.

24 See Aaron \& Schwartz, supra note 21, at 418; Mark V. Pauly, Taxation, Health Insurance, and Market Failure in the Medical Economy, 24 J. ECON. LITERATURE 629, 647 (1986). From 1950 to 1970, the proportion of hospital expenses paid out of pocket by patients decreased from $30 \%$ to $9 \%$. See HenRY J. Aaron, SERIOUS AND UnSTABLE CONDITION: FINANCING AMERICA'S HEALTH CARE 39 (1991) [hereinafter SERIOUS AND UNSTABLE]. As of 1987, patients' share of each dollar devoted to health care was about 10 cents, and their share of each dollar paid to physicians was about 26 cents. See Aaron \& Schwartz, supra note 21, at 418.

2542 U.S.C. \$ $1395 l$ (1988 \& Supp. I 1989); see also 5 BERTRAM HARNETT \& IRVING I. LESNICK, THE LAW OF LIFE AND HEALTH INSURANCE app. III, at T-48 to T-50 (1991) (describing some typical exclusions to coverage). 
while others based their payments on the average amounts claimed for specific services by the providers in a community. ${ }^{26}$

Insulation from costs encourages patients to select providers on the basis of perceived quality and to disregard differences in fees or charges among providers. ${ }^{27}$ This propensity of patients causes providers to compete by attempting to offer better quality, which often means investing heavily in new medical technology. ${ }^{28}$ Protection from costs also encourages patients to consume more care than they would without insurance or health plan coverage. ${ }^{29}$ It also allows providers to select patient management strategies without regard to costs, as there is little or no risk that the care provided will not be paid for. That encourages physicians to recommend any care that might help a patient, especially if the patient is seriously ill, even if it is not certain that the care will be beneficial. The absence of cost pressures also allows providers to plan a course of treatment without regard to the efficiency with which services are provided and without regard to the comparative costs of alternative therapies.

\section{The Provision of Unnecessary Care}

A second major factor alleged to contribute to increasing health care expenditures is the provision of substantial amounts of unnecessary health care due to a lack of knowledge about the circumstances under which various kinds of medical services and products are effective. Some researchers have estimated that $20 \%$ to $30 \%$ of all health care services provided to patients are not necessary. ${ }^{30}$ The problem proceeds from the availability of

${ }^{26}$ See, e.g., EILERS, supra note 3, at 178-209; Regina L. Herzlinger, How Companies Tackle Health Care Costs: Part II, HARV. Bus. Rev., Sept.-Oct. 1985, at 108, 115-17.

27 See MONICA NOETHER, FEDERAL TRADE COMM'N, COMPETITION AMONG HOSPITALS 7 (1987); see also DEAN E. FARLEY, U.S. DEP'T OF HEALTH \& HUMAN SERVS., COMPETITION AMONG HOSPITALS: MARKET STRUCTURE AND ITS RELATION TO Utilization, COSTS AND FINANCIAL POSITION 4-6 (1985) (discussing the market considerations related to physician and hospital competition); Carl J. Schramm \& Steven C. Renn, Hospital Mergers, Market Concentration and the Herfindahl-Hirschman Index, 33 EMORY L.J. 869, 883-84 (1984) (noting the role of the physician as the "purchaser" of services because of the patients lack of sophistication).

${ }^{28}$ Providers have little incentive to compete by offering lower prices because doing so does not attract patients. Therefore, providers have little incentive to reduce costs by becoming more efficient. The net result of increased demand, decreased price responsiveness, incentives to invest in technology, and the lack of incentives to realize efficiencies is higher prices. See supra note 27.

29 See supra note 24 and accompanying text.

${ }^{30}$ See, e.g., Kelly \& Kellie, supra note 11, at 1119-20. Researchers have discovered 
insurance and government health plans. When a patient and physician are in doubt as to whether care will benefit a patient, the service is usually provided because there is little risk of nonpayment. There is also no incentive to examine medical care closely to better determine the circumstances under which it benefits a patient.

\section{Professional Liability}

Costs associated with professional liability also increase health care expenditures. These costs include malpractice premiums and a phenomenon known as "defensive medicine" (where physicians provide medical care to guard against malpractice liability even though the benefits of the care are uncertain). ${ }^{31}$ Malpractice premiums for physicians have increased at an annual rate of $15.1 \%$ during recent years, totaling $\$ 5.6$ billion in $1989 . .^{32}$ The estimated cost of defensive medicine was $\$ 15.1$ billion in $1989 .^{33}$ Together, malpractice premiums and defensive medicine totaled about $\$ 20.7$ billion in 1989 , or about $18 \%$ of all expenditures on physician

that there are wide variations in the rates at which certain medical services are provided to similar populations in different geographic areas with no discernible differences in outcomes. See Leape, supra note 11, at 42; supra note 11 . This discovery has led the researchers to question whether the population that received the service at a higher rate really benefitted and whether it was necessary or appropriate for certain individuals in that population to receive the services.

Another group of researchers built upon this work by carefully reviewing the records of patients who received certain services. They concluded that a substantial amount of the services, more than $30 \%$ in some cases, was unnecessary and should not have been provided. See Kelly \& Kellie, supra note 11, at 1120 . These discoveries have generated a movement to reexamine medical care to better evaluate when it should be provided. See id.

${ }^{31}$ Defensive medicine practices include more extensive recordkeeping, the ordering of diagnostic tests and services of questionable necessity, and spending more time with patients. Perhaps the most prevalent form of defensive medicine is ordering diagnostic tests when the tests are not clearly indicated by the patient's symptoms, but where there is a remote chance that the tests might reveal an illness or injury. The tests are ordered because of fear that if the patient does have a problem that the test could have detected, the physician would be held liable for not ordering the test. See Center for Health Policy Research, American Med. Ass'n., The Cost of Medical Professional Liability in the 1980s, at 2 (1990) (unpublished manuscript, on file with the Center For Health Policy Research) [hereinafter Medical Liability in the 80s]. For methodology and estimates for earlier years, see Roger A. Reynolds et al., The Cost of Medical Professional Liability, 257 JAMA 2776 (1987). Insurance facilitates defensive medicine because physicians and courts can be confident that the care will be paid for.

32 See Medical Liability in the $80 \mathrm{~s}$, supra note 31 , at 1 .

${ }^{33}$ See id. at 2. 
services. $^{34}$

\section{B. Factors External to the Health Care System ${ }^{35}$}

\section{Advances in Medical Technology}

A major factor causing increased volume and intensity of health care services is rapidly advancing medical technology. A contributing factor to technology advances is the widespread provision of health plans that provide the money necessary to finance research and development. Entities that succeed in developing new products that advance patient care are assured of sales. Providers competing on the basis of quality are quick to adopt new technology, and they can be assured of passing on the acquisition costs to insurers and government plans. As a result, a range of new diagnostic equipment

${ }^{34}$ See id.

35 An important factor, one that does not increase volume, is medical inflation. The prices of most goods and services traded in the U.S. economy have risen during the past three decades, but prices for medical goods and services have risen faster than others. As measured by the Consumer Price Index (CPI), prices for medical care increased almost 66\% more than prices for all consumer items from 1965 to 1989. During the period 1980-1989, the CPI for medical care increased by $99 \%$, compared to $46 \%$ for shelter, $33 \%$ for transportation, and $40 \%$ for food. See BUREAU OF LABOR STATISTICS, U.S. DEP'T OF LABOR, CPI DETAILED REPORT 16 (Dec. 1990).

The factors previously discussed, the effects of health insurance, medical technology, increased demand caused by an aging population, costs associated with professional liability, and costs imposed by government regulations, are obvious causes of medical inflation. But there are other factors as well. Wages in the health care sector have risen faster than in the rest of the economy. Increases in wages of rank and file health care workers, those with a college education or less, surpassed those of employees in the rest of the service sector by $1.3 \%$ per year from 1979 to 1985. See Victor R. Fuchs, The Competitive Revolution in Health Care, HEALTH AFF., Summer 1988, at 5, 14. These increases in part reflect an effort by health care workers to achieve pay levels consistent with persons employed in other industries (historically rank and file health workers were paid less than employees in other industries). Of course, these increases were made possible by the increasing demands for care due to the factors discussed above.

Another reason for medical price inflation is the rate of productivity growth in health care compared to other industries. Health care is primarily a service industry characterized by lower productivity growth than manufacturing, a phenomenon attributed to the labor intensity of service production. During the past century, manufacturing industries have achieved substantial productivity gains from the routinization of production and the substitution of capital for labor. Productivity growth in manufacturing has helped offset wage increases and also tends to keep the prices of commodities low relative to the price of services. In the health care sector, productivity growth has been relatively slower, thereby contributing to inedical price inflation above the general rate of inflation. See William J. Baumol, Containing Medical Costs: Why Price Controls Won't Work, PUB. INTEREST, Fall 1988, at 37, 44-45. 
and therapeutic interventions have been rapidly introduced and widely disseminated in the health sector for several decades. These new services increase volume because they increase the number of people who may benefit from therapy. It is also believed, however, that new medical technologies are often introduced without adequate evidence that they are beneficial for the range of patients who use them. ${ }^{86}$

\section{Aging Population}

Demographic trends also have increased the volume of health care services. The proportion of the U.S. population over age sixtyfive has been steadily increasing. Generally, the elderly have greater health care needs than the young and generate much higher average health care expenditures. ${ }^{37}$

${ }^{36}$ Some of the new products permit therapeutic interventions that were not possible before the technology was developed. Other innovations improve on existing diagnostic and medical therapies or reduce the pain or risk of certain invasive procedures. Certain of these products add to health care costs because they are expensive, and also because they tend to increase the number of patients who can benefit from therapy. For example, the cost of AZT, a drug which can delay the onset of AIDS, is expected to be $\$ 5$ billion annually. See Peter S. Arno et al., Economic and Policy Implications of Early Intervention in HIV Disease, 262 JAMA 1493, 1496 (1989). Some advancements, however, such as those which substitute noninvasive procedures for complicated surgical procedures, can reduce health care costs. See Victor R. Fuchs, The Health Sector's Share of the Gross National Product, 247 SCIENCE 534, 537 (1990). Further, the introduction of new drugs may reduce treatment costs for certain diseases by reducing recovery time. But the general consensus among economists is that the net effect of advances in technology increases health care expenditures by increasing the number of patients who may benefit from diagnostic or treatment products. See Aaron \& Schwartz, supra note 21.

${ }^{37}$ For example, in 1987 per capita spending on health care was $\$ 745$ for people under age 19, compared with $\$ 5360$ for those ages 65 or over, and $\$ 9178$ for people age 85 or over. See SERIOUS AND UNSTABLE, supra note 24 , at 42-43. Typically, health care spending for individuals is highest very late in life. About $30 \%$ of the total Medicare expenditures are incurred by the $6 \%$ of enrollees who are in their last year of life. See James Lubitz \& Ronald Prihoda, The Use and Costs of Medicare Services in the Last 2 Years of Life, HEALTH CARE FIN. REV., Spring 1984, at 117, 117. The effects of this demographic trend is expected to continue throughout the 1990s and into the next century. Additionally, the population of the United States is increasing by about $1 \%$ per year, which results in a small annual increase in health care expenditures. 


\section{Proposed Solutions for the Problem of Access AND INCREASING COSTS}

As was stated earlier, two types of solutions have been proposed to resolve the cost problem. The optimistic solution is to eliminate the inefficiencies caused by internal dysfunctions in the health care system; the pessimistic solution holds that rationing is inevitable due to pressures external to the health care system that cannot be changed and, therefore, the focus should be upon developing superior forms of rationing. ${ }^{38}$ The optimistic solution has been embraced by numerous scholars, policy makers, politicians, and interest groups, and it has been incorporated into numerous health system reform proposals. ${ }^{39}$ These proposals aim to expand access to care and to control costs. Many of these proposals have become bills that are pending in Congress and various state legislatures. ${ }^{40}$

The pessimistic solution can be divided into explicit rationing and implicit rationing. Given the assumption that there are insufficient resources to provide all needed health care for all people, advocates of explicit rationing see the key issue as how to. equitably distribute health care services. They would resolve the problem of the uninsured and the underinsured by expanding access, but then applying explicit rationing criteria to determine what needed health care services would be provided, and the conditions under which needed services would be withheld. Most advocates of explicit rationing argue for the development of explicit rationing criteria through an open and democratic process to assure adoption of an allocation system that is acceptable to society as a whole. ${ }^{41}$ Explicit rationing has generally not been embraced and included as part of health system reform proposals. In Oregon, however, there is a proposal for explicit rationing that would affect only the impoverished portion of the population. ${ }^{42}$

${ }^{38}$ See supra text accompanying notes 10-14.

${ }^{39}$ See supra note 9.

40 See supra note 9 . The aggravation of implicit rationing has added force to the long-standing political movement to provide health care for all U.S. citizens. The political pressure from those without access to care has increased as their numbers have risen. In addition, the sense of moral obligation from those with access to care to provide for those without has been amplified by fear. Those with access are afraid they could suddenly find themselves uninsured. As a result, reform of the health care system to assure wide scale coverage of the population has become a potent political issue. See Noble, supra note 9, at 26-28.

41 See supra note 13 and accompanying text.

12 See Letter from Barbara Roberts, Governor of Oregon, to Louis Sullivan, M.D., 
Most advocates of new forms of implicit rationing believe that health care costs can best be controlled and brought into balance by market forces. True to the term of "implicit" rationing, these proposals are generally not promoted as rationing schemes. One would give individuals freedom to select different levels of coverage at different prices. ${ }^{43}$ The coverage differentiations would be much more sophisticated and complex than those of today. Individuals could select plans that would cover different methods of treating the same illnesses or injuries-for example, a more or less resource intensive treatment. While this plan could expand access, it would allow variations in the quality of care provided. ${ }^{44}$

If the bills pending in Congress are an indication of the political salability of various reform proposals, then rationing schemes that apply to all citizens are eventually considered to be politically infeasible by congressional representatives. Virtually all of the bills push the optimistic solution. They can be divided into two major groups, one sponsored primarily by Democrats, the other primarily by Republicans. Both sets rely heavily on the development of guidelines to identify and eliminate unnecessary care.

The Democratic proposals would provide a means to finance health care for virtually all Americans, either through universal coverage funded by federal and state governments, or by mandating employers to provide health insurance to all employees and creating or expanding government programs to cover all other persons. ${ }^{45}$ These proposals would control costs by regulating the charges of health care providers, by setting budgets for total spending, and by setting budgets for spending on the services of various types of providers within defined geographic areas.

The budgets would be intended to control volume. Providers would be responsible for meeting their expenditure budgets for the patient population served by them. Compliance with budgets would be facilitated by regulating medical decisionmaking to eliminate

Secretary of Health and Human Services (Aug. 16, 1991) (on file with author) (includes copy of Oregon's proposal).

43 See Havighurst, supra note 14.

${ }^{44}$ Individuals without funds to purchase quality practice parameters will experience implicit rationing because a person's financial ability directly effects the quality of care they receive.

${ }^{45}$ For a sample of recent Democratic congressional bills aimed to reduce and eliminate inefficiencies in the health care system, see HEALTH REFORM Proposals, supra note 9 (summarizing H.R. 3626, H.R. 1300, S. 1446, H.R. 3205, S. 1227, and H.R. 3410). 
unnecessary health care, by regulating the introduction of new medical technology to eliminate new services of questionable benefit, and by reforming the professional liability system to reduce the costs of malpractice litigation and defensive medicine. Government agencies would draft practice guidelines for physicians to use in the clinical management of patients, and they would monitor physician compliance with them. The guidelines could also be used in malpractice litigation. The federal Medicare program is already using some of the procedures that have been proposed by the Democrats.

The Republican proposals would provide financial assistance to those persons who could not purchase their own health plans, but would make them responsible for selecting and making the actual purchase. The objective is to use market forces to discipline private payers and providers, but to avoid the implicit rationing that normally accompanies market operations by enabling all individuals to purchase an acceptable health care plan. ${ }^{46}$ To control costs, this group would rely upon market forces, assisted by regulations designed to promote managed care health plans that make efforts to control provider charges and utilization. In addition, the professional liability system would be reformed to reduce costs attributable to defensive medicine and malpractice litigation. Sponsors of these bills contemplate that private efforts to control costs would be facilitated by the development of guidelines and other information that would assist payers and providers in eliminating unnecessary care. The market techniques that would be employed by the Republican proposals are already in use in the private sector. ${ }^{47}$

46 See President's Program, supra note 9, at 1, 17.

${ }^{47}$ See Edward B. Hirshfeld, Should Third Party Payors Of Health Care Services Disclose Cost Control Mechanisms To Potential Beneficiaries?, 14 SETON HALL LEGIS. J. 115, 121 30 (1990) (comparing governmental cost-control techniques (prospective payment systems and diagnostic related groups) to cost-control techniques used by private health insurance plans). Market techniques attempt to control price levels primarily by creating competition among providers over prices. This is done by forcing providers to bid against each other for contracts to provide services to health plan beneficiaries. Providers who do not win a contract with a health plan will not be allowed to treat the beneficiaries of that plan. This process may be combined with techniques designed to make beneficiaries more sensitive to price levels when seeking health care. Beneficiaries might be required to make a co-payment (a percentage of the provider's charge) when purchasing services, or incur financial penalties by selecting a high cost provider when a lower cost provider is available. See KIRK B. JOHNSON ET AL., AMERICAN MED. ASS'N, LEGAL IMPLICATIONS OF PRACTICE PARAMETERS 61-66 (1990) [hereinafter LEGAL IMPLICATIONS]. 
Given the heavy reliance that both the Democratic and Republican plans place on the identification and elimination of unnecessary care, an important issue is to define unnecessary care. The issue is important because the boundary line between needed and unneeded care is also the border between rationing and the withholding of unnecessary care. ${ }^{48}$

\section{THE CONCEPT OF UNNECESSARY CARE}

Although the development of guidelines to distinguish necessary from unnecessary care is essential to the success of both the Republican and the Democratic reform proposals, the science of developing guidelines is in its infancy and is not well developed. ${ }^{49}$

Market techniques attempt to control volume by forcing providers to be responsible about the amount of care that they recommend to patients. One method involves creating financial incentives for physicians to limit the amount of care that they provide to beneficiaries. One type of incentive requires physicians to share the financial risk involved in providing coverage to plan beneficiaries. Risk sharing may be implemented through arrangements that require a provider to provide all necessary care to designated beneficiaries for a fixed amount of money, or by imposing financial penalties for failure to keep the costs of treatment within a budget. However it is arranged, the provider profits if the amount of care provided to the beneficiaries costs less than the amount paid.

Another incentive involves prospective and retrospective review of the care rendered by a provider, with denial of payment for care deemed to be unnecessary. Prospective review places responsibility on the payer to balance the needs of the beneficiary with budgetary constraints; a retrospective review places responsibility on the provider. Yet another method of controlling volume is to develop a practice profile of a physician to compare with other physicians. A physician who tends to provide more care than others for the same medical problem would be counseled, and if he does not respond with lower usage rates, would be barred from treating beneficiaries of the payer.

The provision of vouchers or tax credits that could be used to purchase health plans would buttress efforts to create competition among providers by attracting patients to health plans that do the best job at managing provider costs. At present, employers and other major purchasers of health plans are sensitive to the costs of purchasing health plan participation, but the individuals that they represent are not as sensitive and tend to put pressure on employers and others to purchase plans with features that may make it difficult to control costs.

48 In addition to noting the heavy reliance that the Democratic and Republican plans place on the development of guidelines to eliminate unnecessary care, it should be observed that both sets of plans could evolve into implicit rationing schemes if they are underfunded. The Democratic plans could evolve into queuing and the Republican plans could result in market based implicit rationing. In addition, they could also result in rationing if the guidelines used to distinguish necessary from unnecessary care evolve into rationing devices. That could occur explicitly, or it could occur implicitly by using the guidelines to narrow the concept of what constitutes necessary care.

${ }^{49}$ See supra note 20 and accompanying text. 
Further, development of the science will not be easy, and presents certain moral dilemmas. These dilemmas are caused by two factors. One is the uncertainty inherent in much of medical practice. The other is differences in the degree of benefit that various services provide in ameliorating an illness or injury.

For any patient suffering from an illness or injury, there generally is agreement on what health care services will almost certainly yield a benefit for a patient, and on what services will almost definitely not be beneficial. However, there also is a zone of uncertainty about whether other health care services will benefit the patient. The uncertainty may result from variations in the gravity of symptoms suffered by the patient, or questions about the range of illnesses or injuries for which a medical service is effective, or other issues. Identification of unnecessary care requires the assignment of a degree of probability that a service will help a patient, and a decision about when this probability is high enough to consider the service necessary. The dilemma is defining the degree of probability that should be required before the care is considered necessary. ${ }^{50}$

Similarly, for any given patient, certain services may almost completely cure or resolve an illness or injury, while others provide only partial relief or do no more than provide some level of comfort to the patient. The extent to which services will ameliorate a medical problem or provide comfort may be identifiable with some degree of certainty. However, the question is what degree of benefit should be required before a service is considered to be needed by the patient.

It is plain that the concept of unnecessary care contains an objective medical science component, which is information about the probability or extent that a medical service will benefit a patient, and a normative value judgment component, which is whether the service is worth providing given the probability or extent that the patient will benefit from it. Once a conclusion is reached as a matter of medical science about the benefits of a service for a patient, then a value judgment can be made about whether it is

${ }^{50}$ For an example of a guideline which works through these issues, see Subcommittee on Pacemaker Implantation, Joint Am. College of Cardiology/Am. Heart Ass'n Task Force on Assessment of Cardiovascular Procedures, Guidelines for Permanent Cardiac Pacemaker Implantation, May 1984, 4 J. AM. C. CARDIOLOGY 434 (1984). For a discussion of approaches that have been developed to quantify the likelihood of a benefit, see Chassin, supra note 20, at 443-46. 
necessary. Some of the value judgments are easy to make, others are more difficult. ${ }^{51}$

The scientific judgment about the likely benefits of medical services proposed for the diagnosis or treatment of an illness or injury can hypothetically be ranked on a vertical continuum. At the top of the continuum are services that definitely will help the patient or that have the highest probability of doing so. At the bottom are services that definitely will not help. In between are services that have some degree of probability of helping the patient-those higher on the continuum have a higher degree of probability of helping than those that are lower.

The easy value judgments to make about necessity are for medical services that are at the top and bottom of the continuum. Most people would agree that patients should receive services that definitely will help them, and most people would agree that there is no reason to provide services that definitely will not help patients. The harder value judgments are for services in between-those that may or may not help patients. The question is how far down the continuum services should be considered necessary.

At present, there is no standard medical terminology for expressing either the probability or extent that a procedure or medical service will help a patient, and there is no generally accepted methodology in medicine for making the value judgment about whether care is necessary. ${ }^{52}$ Traditionally, services have been provided to patients when there is a low probability that the services will be beneficial, especially if there are no other services available with a higher degree of probability of providing a benefit, the risk of iatrogenic harm is low, and the patient is gravely ill or insistent upon ameliorating a medical problem. Similarly, services tend to be provided under the same conditions even when they will provide a low degree of benefit. It has been considered in the best interests of the patient to provide care under those circumstances.

The current challenge for physicians is to reexamine the range

${ }^{51}$ See Edward B. Hirshfeld, Economic Considerations in Treatment Decisions and the Standard of Care in Medical Malpractice Litigation, 264 JAMA 2004, 2004 (1990) (noting the tension between patients' interests and "society's need to control health care expenditures").

52 For analyses of the problems associated with the use of practice guidelines and their effectiveness in reducing malpractice litigation, see Deborah W. Garnick et al., Can Practice Guidelines Reduce the Number and Costs of Malpractice Claims?, 266 JAMA 2856 (1991); Edward B. Hirshfeld, Should Practice Parameters Be the Standard of Care in Malpractice Litigation?, 266 JAMA 2886 (1991). 
of medical services and products available and closely evaluate the extent to which they provide a benefit to patients with an illness or injury. The object is to eliminate as much uncertainty as possible about the extent of the benefit provided by a service or product. Obtaining a better understanding of the benefits realized from care will place more medical decisions into the "easy" value judgment category, because physicians will learn more about whether certain care definitely does or does not confer a substantial benefit to a patient with a given illness or injury. However, after that is accomplished, the question will remain about how to make the hard value judgments-where the line is drawn on the degree of probability or benefit required before services are considered necessary will define what constitutes the denial of inappropriate care as opposed to rationing.

Given that hard value judgments have to be made, the question arises as to who will ultimately make them, what existing process will be used to make the value judgments, what standards or principles will be followed in making the judgments, and whether those principles should be changed to facilitate the goals of controlling costs by eliminating unnecessary care. Physicians will have an important voice in making the value judgments, but courts will have the decisive role in the absence of legislation. Where the border between necessary and unnecessary care is set will also define the difference between the appropriate provision of care and malpractice, as the failure of a physician to provide or recommend needed care constitutes malpractice.

Therefore, the standard of care in medical malpractice litigation will be the vehicle for setting the border unless a legislature imposes a definition of necessity on the courts. The question is whether the process and principles by which the standard of care is developed are adequate to make the value judgments involved, or whether the process or principles should be changed to facilitate the goal of eliminating unnecessary care.

\section{How THE STANDARd of CARE is DeVEloped}

Currently, the standard of care is the ultimate test for physicians and payers when evaluating whether care should be provided or withheld from a patient. ${ }^{53}$ However, the courts have not done any

${ }^{53}$ Federal policymakers rely on the tort liability system to prevent abuse from the incentives imposed on physicians and hospitals by cost control mechanisms in the 
better than physicians in developing clear guidelines about where to place the boundary between necessary and unnecessary care, or about how to make the hard value judgments. ${ }^{54}$ For example, there is no rule of law which states that medical services are necessary if there is a ten percent chance that they will help a patient, and unnecessary if there is a lesser probability.

Medical malpractice litigation begins when a patient who has suffered an adverse outcome files a lawsuit against a physician alleging that the bad outcome was caused by the physician's negligence. In order to recover damages against the physician, the patient must prove four elements: (a) that the physician owed a duty of care to the patient, which is proven by showing formation of a physician-patient relationship, (b) that the physician breached the duty by failing to exercise reasonable care in providing treatment, (c) that the patient's injury was proximately caused by the breach of duty, and (d) that the patient suffered a compensable injury. ${ }^{55}$

A key element in this order of proof is proving that the physician violated the duty to exercise reasonable care, which is proven by showing that the physician failed to meet the standard of care. However, there is no list of standards of care from which a patient or a court may choose from for use in a particular malpractice case. Instead, the specific standard of care applicable to how a patient was treated must be proven in each case-it is not legally predetermined. A preexisting list of standards of care has not been created for use in malpractice litigation because of the vast diversity in the characteristics of patients and their problems. It is not feasible to develop a predetermined standard of care for every possible clinical problem that a physician might confront. ${ }^{56}$

Instead of being drawn from a list, the standard of care applicable to a physician's conduct in a specific clinical situation is determined at trial. Each side introduces evidence about how the standard of care applicable to the case should be defined. The plaintiff normally calls one or more physicians to testify as an expert witness about how the defendant physician should have handled the

Medicare System. See Vance-Bryan, supra note 15, at 1421.

${ }^{54}$ See Clark C. Havighurst, Practice Guidelines as Legal Standards Governing Physician Liability, LAW \& CONTEMP. PROBS., Spring 1991, at 87, $96-99$ (discussing malpractice law standards, characterizing them as "extraordinarily vague and unpredictable," and analyzing their shortcomings).

${ }^{55}$ See PROSSER ON TORTS, supra note $18, \S 80$.

${ }^{56}$ See supra note 18 and accompanying text. 
plaintiff patient. The expert witness has the entire field of medicine available as a basis for testimony. The expert testimony can be supported or supplemented by articles in medical journals, research reports, and other sources of information. The defendant physician normally rebuts by calling physician expert witnesses who testify in support of how the defendant handled the patient, and by introducing other evidence. ${ }^{57}$

After all of the evidence is introduced, the jury, or a judge sitting in place of the jury, determines the standard of care applicable to the case by evaluating the competing evidence introduced by each party. However, the jury is not without guidance in evaluating the evidence. The judge issues instructions to the jury about the law of the case. These instructions create a framework of rules within which the standard of care is determined.

The rules start the jury with a broad standard of care applicable to all medical practice. The jury is instructed to compare the conduct of the defendant physician to what a competent physician exercising the level of knowledge and skill generally possessed and exercised by similarly competent physicians would have done under comparable circumstances. ${ }^{58}$ The broad rule is too vague to help a jury evaluate whether a physician committed malpractice. Therefore, the rules lead the jury down a path of progressively narrower standards which are more applicable to the subject matter of the case until the jury develops the specific standard of care for the clinical situation at issue.

Narrowing standards may direct, for example, that a specialist's conduct be compared to other specialists, ${ }^{59}$ or that the defendant be compared to other physicians practicing in the same geographic locality, ${ }^{60}$ or to physicians who subscribe to the same "school of thought." 61 The court may also direct that a physician who elected to pursue one of the several recognized courses of treatment should

${ }^{57}$ See LEGAL IMPLICATIONS, supra note 47, at 11-13 (reviewing general principles concerning malpractice trials); Havighurst, supra note 54, at 96-97 (discussing how the process of a malpractice trial determines the standard of care).

${ }^{58}$ See Jay M. Zitter, Annotation, Standard of Care Owed to Patient by Medical Specialist as Determined by Local, "Like Community," State, National or Other Standards, 18 A.L.R. 4TH 603, 614-20 (1982).

59 See id. at 616-19.

${ }^{60}$ See id. at 608-11.

61 See, e.g., Becker v. Hidalgo, 556 P.2d 35, 38 (N.M. 1976) (considering and rejecting testimony of expert physician regarding proper means of performing procedure where the expert subscribed to a different school of thought than the defendant). 
not be penalized, so long as the course selected is accepted by at least a "respectable minority" of the profession. ${ }^{62}$ Further narrowings are a matter of competing evidence to be decided by the jury.

In summary, the development of the standard of care is a highly particularized process whereby a set of general principles is applied to develop a standard of care tailored to the unique circumstances of a case. The process is flexible and capable of evolution as medicine evolves and advances. For example, as the profession's technological capability has increased, the standard of care has evolved with it and become more stringent. ${ }^{63}$ An important question is how the value judgments inherent in the development of the standard of care might evolve in response to a societal interest in controlling health care costs.

\section{A. How the Value Judgment is Made}

Development of the standard of care is heavily dependent on the customary and usual practice of the medical profession. ${ }^{64} \mathrm{~A}$ medical malpractice trial often involves a contest to determine what was considered to be good medical practice when the patient involved was treated. The contest is decided by evaluating the testimony and writings of physicians. Some have argued that the dependence on physician custom allows the profession to set its own legal standards of conduct. ${ }^{65}$ If that argument were correct, then physicians would be making the value judgments that are inherent in the standard of care, but that is not the case.

When the issue in malpractice litigation concerns whether necessary medical services were withheld from a patient, or whether substandard services were delivered because of financial incentives

62 See, e.g., Chumbler v. McClure, 505 F.2d 489, 492 (6th Cir. 1974) (holding "[w]here two or more schools of thought exist ... each of which is supported by responsible medical authority, it is not malpractice to be among the minority in a given city who follow one of the accepted schools").

${ }^{63}$ See Richard N. Pearson, The Role of Custom in Medical Malpractice Cases, 51 IND. L.J. 528, 538-57 (1976).

${ }^{64}$ See Joseph H. King, Jr., In Search of a Standard of Care for the Medical Profession: The “Accepted Practice” Formula, 28 VAND. L. REV. 1213, 1236-41 (1975); Pearson, supra note 63, at 528; Neil Meltzer, Comment, Helling v. Carey: Landmark or Exception in Medical Malpractice; Compliance with the Medical Standard of Care May Not Prutect the Specialist from Liability, 11 NEW ENG. L. REV. 301, 301-02 (1975); see also Havighurst, supra note 54, at 96-98 (discussing the "customary-practice" standard).

${ }^{65}$ See King, supra note 64, at 1236; Meltzer, supra note 64, at 302; see also ProssER ON TORTS, supra note $18, \S 32$, at $185-93$ (discussing professional malpractice in relation to concepts of superior knowledge, skill and intelligence). 
to minimize the resources expended on a patient, the standard of care consists of the objective medical science component and the normative value judgment discussed earlier in this Commentary. ${ }^{66}$

The objective medical science component is almost always determined by the medical profession, although sometimes scientists from other disciplines may assist. There are practical reasons why. It takes an extensive education and years of experience to become competent at the art and science of medicine. Due to human limitations, it is not feasible for nonphysician judges and juries to second guess physicians about the likely benefits that services would have had for a patient. Courts are often required to choose between conflicting evidence about what the standard of care should be. However, when that occurs, they are choosing between the opinions of physicians. Further, their ability to choose is restricted by rules such as the "school of thought" or "respectable minority" rules, which require courts to accept differing medical opinions provided that they are each subscribed to by substantial numbers of authoritative physicians.

The value judgment component is made in light of conclusions reached about the likely benefits that services would have had for the plaintiff patient. It involves an evaluation as to whether the services should have been provided given their likely benefits, the risk of iatrogenic harm, and the gravity of the problem experienced by the patient. Normally the value judgment does not involve an explicit consideration of the costs of caring for a patient, although economics are implicitly considered. Physicians do not do everything conceivably possible in caring for a patient-they draw what they consider to be reasonable boundary lines. For example, physicians do not order every diagnostic test available for a patient that requests a physical examination, even though doing so might reveal interesting information. Instead, they order tests which are indicated given the age and physical characteristics of the patient.

Physicians make the initial value judgment about what care is reasonable to provide to a patient, although on many occasions they leave the decision up to their patients. However, the usual and customary practices of the profession are not decisive in determining this component. Courts feel that they can make the normative value judgment as well as physicians. Courts, together with legislatures, act as the vehicle of societal expression about the values

${ }^{66}$ See supra text accompanying note 51 . 
which should guide the decision about whether likely benefits are significant enough to provide services, and the amount of resources that should be expanded on an individual. Courts can exercise this authority by overruling the value judgment made by the physician involved in the malpractice case.

An example of a court overruling the value judgment of physicians and imposing its own is the famous case of Helling $v$. Carey. ${ }^{67}$ In Helling, the issue was whether an ophthalmologist should have tested a twenty-nine-year-old patient for glaucoma during an eye examination. The patient involved had glaucoma, but was not diagnosed before the symptoms became noticeable because the test was not performed ${ }^{68}$ At that time (early 1970s), the prevailing practice among ophthalmologists was not to test a twentynine-year-old patient because the incidence of glaucoma in people that young was very low. ${ }^{69}$ It was not considered worthwhile to test young people. However, the court disagreed, and found that the prevailing practice was inadequate and that the patient should have been tested. ${ }^{70}$

The Helling court did not disagree with the medical science conclusion of ophthalmologists that the incidence of glaucoma in young people was very low. It did not find that physicians were wrong, and that the incidence of the disease was in fact higher. Instead, the court disagreed with the value judgment made by ophthalmologists that testing for glaucoma in young people was not worthwhile, even though the incidence of the disease was very low in that population.

As a practical matter, it is rare for a court to expressly overrule the value judgments that prevail among physicians. That is probably because physicians, judges, and juries are all part of American culture, and have the same societal values. Those shared values include a bias towards providing whatever care might help a sick or injured patient. ${ }^{71}$ Therefore, courts have rarely had to express the value judgment component and it has not been an integral issue in most malpractice cases. Courts have concentrated on developing

67519 P.2d. 981 (Wash. 1974) (en banc). The holding of Helling was reaffirmed in Gates v. Jensen, 595 P.2d 919 (Wash. 1979).

${ }^{68}$ See Helling, 519 P.2d at 981-82.

${ }^{69}$ See id. at $982-83$ (noting that glaucoma occurs in only one out of every 25,000 people under age forty).

${ }^{10}$ See id. at 983 .

71 Cf. Enthoven, supra note 10, at 1230 ("Physicians and other health professionals are motivated by nonfinancial goals, including a desire to cure the sick ...."). 
and applying the scientific component.

Although the courts have the authority to make the value judgment involved in determining whether care should have been provided to a patient, their discretion is not unlimited. The value judgment has to be made within a framework formed by the general principles that are applied in developing the standard of care. In malpractice cases, the context in which the standard of care has been developed is the physician-patient relationship. The issue is what obligation the physician had towards the patient who brought suit, and whether the obligation was discharged.

\section{B. The Limits Imposed on the Judicial Value Judgment by the Patient-Interest Oriented Standard of Care}

While malpractice is a tort claim, the physician-patient relationship is contractual in nature. The contract is created when the physician accepts the request of an individual to become a patient. In fact, malpractice claims were originally brought as actions for breach of contract, and they still can be brought as contract cases. The tort remedy evolved from the breach of contract claim, and the duty involved in tort standard of care is based on a voluntarily assumed contractual obligation. ${ }^{72}$

The contractual obligation upon which the tort duty is implied is inherent in the physician-patient relationship. It is not necessary for the physician to expressly agree to every aspect of the obligation in order for it to be part of the contract between physician and patient. $^{73}$ The implied contractual obligation probably evolved from physician ethics. Physicians held themselves out to the public as adhering to a code of ethics designed to protect patients, a particularly important consideration given the vulnerable position patients are in when they are sick or injured. ${ }^{74}$ Eventually the public came to expect that physicians would adhere to key portions of that code when treating a patient, and the courts converted those expectations into an implied contract, and then a tort duty.

72 See Prosser ON TORTS, supra note $18, \S 30$, at 164 (noting that "duty" is an essential element of any tort claim).

73 See TheOdore R. LeBlang ET al., The LaW of MEdical Practice in IlLiNois $\S 4.2$ (1986).

74 For a presentation of the physician's evolution into the role of an implied fiduciary, see MORRIS FISHBEIN, A HISTORY OF THE AMERICAN MEDICAL ASSOCIATION 1847 To 1947, at 35-40 (1947); PERCIVAL's MEdical ETHICs 10-57 (Chauncey D. Leake ed., 1927). 
Under the implied contractual provision and the tort duty, the physician is, in essence, a fiduciary for the patient. ${ }^{75}$ As is the case with other types of fiduciaries, the physician has an obligation to place the patient's interests above almost all other considerations, especially the physician's own interests. ${ }^{76}$ The main part of this obligation is the requirement that the physician exercise due care and skill in the treatment of the patient. ${ }^{77}$ As part of that obligation, the physician has a duty to provide or recommend the care that is needed by a patient, and to administer the care competently. The courts are the interpreters of the degree of skill that a physician is expected to have and to exercise when caring for a patient. Determining the standard of care in a malpractice case is an exercise in evaluating the level of skill that should have been applied by the physician in the circumstances of the case.

However, the fiduciary relationship that exists between a physician and patient goes further than requiring that a physician exercise an acceptable level of skill and care during the treatment of a patient. It is inherent in a fiduciary relationship that the fiduciary act in the best interests of the person who has entrusted the fiduciary. ${ }^{78}$ Therefore, a physician has an independent obligation to act in the best interests of the patient beyond the requirement that the physician exercise skill; merely acting as a good technician is insufficient. This obligation is probably a greater restraint on the withholding of needed services by a physician than is the requirement that the physician exercise an adequate level of skill. It prevents the physician from paying excessive attention to the societal interest in conserving resources when caring for a patient.

75 See PhySICIANS, SURgeONS, AND OTHERs, supra note $18, \S \S 166-168$. But not all agree that it is clear that a physician is, or should be, a strict fiduciary for the patient. For a discussion of this perspective, see Mehlman, supra note 14, at 367-70 (describing how the physician-patient relationship does and does not resemble traditional fiduciary relationships); E. Haavi Morreim, Economic Disclosure and Economic Advocacy: New Duties in the Medical Standard of Care, 12 J. LEGAL MED. 275, 296-301 (1991) (setting forth the argument for a more contractual model).

${ }^{76}$ See PHYSICLANS, SURGEONS, AND OTHERS, supra note 18, §§ 166-168 (detailing physician's duties as a fiduciary); Morreim, supra note 75, at 300 (noting that physicians must hold to a "professional altruism that places the patient's interests above his or her own"); see also FISHBEIN, supra note 74, at $99-40$ (stating that physicians must "labor[] for the alleviation of . . . suffering without regard to the risk of his own health or life or to financial return").

77 See PHYSICIANS, SURGEONS, AND OTHERS, supra note $18, \$ 167$.

${ }^{78}$ See CODE OF MEDICAL ETHICS, supra note 18, at 34-35 op. 8.03; Morriem, supra note 75, at 300; supra note 76 and accompanying text. 
Therefore, with respect to making value judgments about what care is needed, the courts are limited by their role in interpreting the level of skill that should have been applied by a physician and the physician's fiduciary obligation to the patient. There is some room in this role for evolution of the value judgments away from requiring that care be provided when there is doubt about its ultimate value, and towards requiring that there be a higher probability of known benefits before the care is considered to be necessary. However, there is no room in that role for withholding care which is known to be, or has a reasonable probability of being beneficial. That would be a stark and unacceptable departure from the requirement that the physician exercise a certain level of skill and care in the treatment of patients and act in their best interest. $^{79}$

\section{THE STANDARD OF CARE AND IMPLICIT OR EXPLICIT RATIONING}

Although the standard of care is patient-interest oriented, the standard does not prevent all forms of rationing. For example, it does not bar the kind of market based implicit rationing that exists in the United States today. The reason why is the contractual nature of the relationship between patient and physician. The standard of care does not apply until the physician-patient relationship has been formed, and the relationship is not formed unless it is voluntarily assumed by the physician. ${ }^{80}$ The law does not require physicians to treat any patient that asks for care. ${ }^{81}$ The law does require that a patient-interest standard of care be followed

79 Willful provision of inadequate treatment clearly violates the standard of care and is unethical as well. See CODE OF MEDICAL ETHICS, supra note 18, at 20 op. 4.04.

80 See 2 Michael G. MacDonald, TREatise ON HEalTh CaRE LaW § 11.03[1][c] (1991) ("T T]he obligation of physicians to accept or treat specific patients . . . remains one of mutual contract largely unregulated by state or federal laws."); PROSSER ON TORTS, supra note $18, \S 32$, at $186-87$ (noting that a physician's duty to a patient commences only once she "undertak[es] to render medical services").

${ }^{81}$ See 2 MACDONALD, supra note 80, \$ 11.03[2][c][i]. There are some limitations on this proposition, such as requirements that physicians not discriminate. See, e.g., Americans With Disabilities Act of 1990, Pub. L. No. 101-336, § 102, 104 Stat. 327, 331 (codified at 42 U.S.C.A. $\$ 12112$ (West Pamphlet 1992)) (requiring physicians not to discriminate against AIDS patients or others). Although public hospitals and government health care programs have an obligation to treat all patients with certain characteristics, see 2 MACDONALD, supra note 80, $\$ 11.03[1][$ a] [i] , private hospitals are generally not required to admit every patient that wants care, see id. \$ 11.03[2][b][i]. In addition, private insurers are generally free to set limits on whom they will cover and have no obligation to finance the care of a beneficiary beyond the agreed terms of coverage contained in the health plan contract. See id. $\$ 11.03$ [2][iii]. 
once the physician agrees to care for a patient. ${ }^{82}$ This legal standard is also consistent with physician ethics. The ethical physician provides charitable care, but Principle VI of the AMA Principles of Ethics states that a physician shall "be free to choose whom to serve, with whom to associate, and the environment in which to provide medical services. ${ }^{\text {8SS }}$ Therefore, a physician is not required to care for any specific patient in meeting an ethical obligation to provide charitable care.

Further, a physician is not obligated to care for a patient indefinitely or even as long as the patient needs care for an illness or injury. A physician may sever a relationship with a patient as a matter of law and ethics. To withdraw from a relationship, the physician must give the patient sufficient notice for the patient to find a new physician, and must continue caring for the patient during the notice period. ${ }^{84}$ However, the physician does not have to care for the patient after the notice period is over if the patient has not been able to find another physician. ${ }^{85}$ Therefore, a physician can withdraw from a physician patient-relationship if a patient runs out of financial resources and can no longer afford to pay for care. If a physician recommends that a patient receive certain services, but the patient runs out of insurance coverage or the insurer refuses to finance the services recommended, the physician may withdraw from the relationship.

In addition, a physician is not obligated to provide a patient with the services of other providers, such as hospitals, other types of health facilities, other physicians, or other health care professionals, if those providers will not accept the patient. ${ }^{86}$ A physician may be willing to provide charitable care to an uninsured patient, but cannot force other providers to do the same. Physicians also cannot force hospitals or other providers to continue caring for a patient if the patient runs out of resources during a hospital stay or during the course of a treatment, and they cannot force payers to continue financing the care of a patient after the cost of a patient's care has gone beyond the limits of coverage in a health plan.

Further, the patient-interest oriented standard of care is not

82 See PROSSER ON TORTS, supra note 18, § 32, at 186-87; supra note 18.

83 CODE OF MEDICAL ETHICS, supra note 18, at $\mathrm{x}$.

${ }^{84}$ See CODE of MEdical ETHICS, supra note 18, at 39 op. 8.11; Physicians, SURGEONS, AND OTHERS, supra note 18, \$§ 234-238.

85 See CODE OF MEDICAL ETHICS, supra note 18 , at 39 op. 8.11 .

${ }^{86}$ An exception to this is when a physician group has a contractual obligation to provide care pursuant to an HMO or other contract. 
incompatible with all forms of explicit rationing. In fact, it would be possible to implement many kinds of explicit rationing schemes under current legal and ethical standards. All that is necessary is to structure explicit rationing so that it does not collide with the physician's obligation under the patient-interest oriented standard of care. For purposes of analyzing how explicit rationing could be implemented without conflicting with the patient-interest standard of care, it is helpful to divide the standard into two components. One component is the duty to determine what care is necessary and recommend to the patient that it be provided; the other is the duty to exercise due care in the provision of treatment. As previously discussed, there generally is no duty to provide the care recommended unless the physician has voluntarily agreed to provide the services. The critical aspect in how rationing schemes interact with the patient-interest oriented standard of care is how they influence the physician's recommendations for what care should be provided.

If the predetermined criteria for explicit rationing are applied to a patient before being seen by a physician, then the patientinterest oriented standard of care would not apply at all. This could be accomplished with schemes that ration care according to age or other nonmedical criteria. If a physician sees a patient and recommends that certain care be provided, but the explicit rationing scheme bars the funding of the type of care recommended, or actually bars the patient from receiving the care, the physician would have no obligation to provide the services and the patientinterest oriented standard of care would not apply. Similarly, if a physician recommended that a certain type of care be provided, but an explicit rationing scheme allocated a fixed amount of funds to the patient that was insufficient to pay for the care, the physician would not have an obligation to provide the services and the standard of care would not be violated.

The area in which rationing collides with the standard of care is where it affects the recommendations for care made by the physician. For example, if physicians are given guidelines that recommend care which may not satisfy the patient-interest standard of care, ${ }^{87}$ and less than optimal recommendations are in fact made, the physicians could be liable for any injuries to patients attributable to the recommendations. ${ }^{88}$ At present then, the

${ }^{87}$ Widespread denials of needed care made as a result of such arrangements would clearly constitute a form of rationing.

${ }^{88}$ See PROSSER ON TORTS, supra note 18 , § 32, at 185-89; supra note 18. 
patient-interest oriented standard of care prevents physicians from making recommendations that result in denials of needed care to patients. ${ }^{89}$

\section{WHETHER THE PATIENT-INTEREST ORIENTED STANDARD OF CARE SHOULD BE CHANGED}

Some commentators have suggested that the standard of care be changed to allow physicians greater leeway in recommending that care not be provided to a patient. ${ }^{90}$ These commentators recognize that there is a limit to how much the standard of care can evolve to accommodate a societal interest in conserving costs when physicians make recommendations to patients about what care is needed to diagnose or treat an illness or injury. They believe that the standard of care should account for a more substantial societal interest in conserving costs than may be feasible under the current patient-interest oriented standard. ${ }^{91}$

The standard of care could be changed by legislation or through evolution in the courts. One method of change would be to alter the broad principles that underlie the standard to make them less patient-interest oriented. For example, legislation could impose a rule which provided that care would not be deemed necessary unless it had a high probability of resulting in a substantial benefit to the patient. ${ }^{92}$

A more likely method of change involves the development of guidelines designed to distinguish between necessary and unneeded care. Governments could draft guidelines that physicians would be allowed or required to use and which courts would be required to apply as standards of care. ${ }^{93}$ The guidelines would specify the

${ }^{89}$ See Hirshfeld, supra note 47 , at $117,135-38$.

90 See supra note 15.

91 See Morreim, Cost Containment, supra note 15, at 1745-63 (reviewing strategies to change the law so that it accommodates "cost constraints" and concluding that the best option is to change the "standard of care" into a "rebuttable presumption"); Morreim, Scarcity, supra note 15, at 359-63 (proposing a new standard of care composed of two elements, one being a "Standard of Resource Use").

92 Another way would be to inject a cost consideration into the standard, and have physicians balance a duty to society to control costs against their duty to the patient. A third way would be to provide a defense for physicians who treat patients without access to sufficient financing for health care. See Morreim, Cost Containment, supra note 15 , at 1757-63. The defense would allow physicians to demonstrate that they recommended or provided the best care feasible for a patient given the financial resources available. See id.

${ }^{93}$ For discussions about government-imposed guidelines as the standard of care, 
patient management strategies required for patients with certain medical problems. Drafters of the guidelines would balance the need to conserve costs against the needs of individual patients when considering what patient care strategies to include for the treatment of various medical problems. The guidelines could set the boundary between necessary and unneeded care at a different point than would a court applying the patient-interest oriented standard of care. The guidelines could allow or require that the cheaper of two alternatives be used to treat a patient even though the more expensive methods might be more effective or less likely to cause iatrogenic injury.

This approach is likely because guidelines designed to distinguish between necessary and unnecessary care are in fact under development by governments and many private organizations. ${ }^{94}$ In fact, one state, Maine, has implemented a demonstration project whereby state approved practice guidelines may be used by physicians in caring for patients, and adherence to an approved practice guideline may be used as a defense in a malpractice action. ${ }^{95}$ It is easy to see how the need to control costs could cause governments to adopt guidelines that are weighted towards the societal interest in conserving resources. The lack of a clear methodology to use in making the hard value judgments could

see Havighurst, supra note 54, at 105-07. For a discussion of other ways that guidelines could impact the standard of care, see Troyen A. Brennan, Practice Guidelines and Malpractice Litigation: Collision or Cohesion?, 16 J. HEALTH POL. POL'Y \& L. 67 (1991); Mark A. Hall, The Defensive Effect of Medical Practice Policies in Malpractice Litigation, LAW \& CoNTEMP. ProBS., Spring 1991, at 119, 129-45; Havighurst, supra note 14, at 816-19; Eleanor Kinney, Medical Practice Guidelines and Medical Liability: Evolutionary Trends and Future Implications (unpublished article on file with the author, forthcoming in a RAND publication, 1992); Richard E. Leahy, Rational Health Policy and the Legal Standard of Care: A Call for Judicial Deference to Medical Practice Guidelines, 77 CAL. L. REV. 1483, 1495-1505 (1989).

91 In 1989, Congress created the Agency for Health Care Policy and Research (AHCPR) and a unit of AHCPR called The Forum for Quality and Effectiveness in Health Care to pursue the development of practice guidelines, among other matters. See Omnibus Budget Reconciliation Act of 1989, Pub. L. No. 101-239, § 6103, 103 Stat. 2106, 2189 (codified at 42 U.S.C. $\$ \S 299,299 b-1$ to -3 (Supp. I 1989)). For a summary of efforts to create guidelines by physician organizations, see Kelly \& Swartwout, supra note 20, at 54-57. For a summary of such efforts by others, see Kinney, supra, note 93, at 6-8.

95 See ME. REV. STAT. ANN. tit. 24, \$§ 2971-2978 (West Supp. 1991); see also 42 U.S.C. $\$ 1320 c-6$ (c) (1988) (limiting liability of physicians who reasonably rely on a professionally developed norm of care and treatment applied by a peer review organization under contract with the United States Department of Health and Human Services). 
facilitate such weighing because it might not be immediately clear that it was occurring. A shift towards the societal interest would be even harder to notice if it occurred slowly over time, so that a substantial shift was not detectible in the drafting of any particular guideline.

Of all the alternatives suggested to facilitate the volume and intensity of care, this approach seems to be the least desirable for a number of reasons. First, changing the standard of care by placing a greater weight on economic considerations at the expense of the patient's interests would dramatically alter the fiduciary nature of the physician-patient relationship. The physician would be given a duty or permission to consider matters that were not necessarily in the patient's interest when evaluating a course of treatment, and might even be required or allowed to recommend a course of care that was not optimal. The patient would no longer be able to have confidence that the physician was oriented around the patient's best interests. The fiduciary element of the physicianpatient relationship has long been embraced by society as valuable and desirable. Given that sick or injured patients are often in a vulnerable state, and given that they do not have the medical knowledge necessary to evaluate their own problems, society has considered it important that patients be able to place trust and confidence in physicians. This relationship is one that should not be modified or given up without deep consideration, for if we give it up we will have lost something that is beyond monetary value.

Second, changing the standard of care to accommodate a societal interest in conserving costs would be more difficult than it first appears. If the standard is changed to require a balancing of societal interests in conserving costs against the needs of the patient, the question will become how to accomplish that balancing in a consistent and equitable manner. Each medical situation is unique, and it will be difficult to decide, on a case by case basis, when it is appropriate to deny care that could benefit the patient.

Third, if rationing becomes necessary, there are ways that it can be accomplished without changing the standard of care. As has already been discussed, the patient-interest oriented standard of care can accommodate explicit rationing. Criteria for explicit rationing can be developed pursuant to an open and democratic process, and then observed by physicians and patients. That would leave physicians free to evaluate a patient and make recommendations based on what the physician believes to be in the patient's best interests, and then the rationing criteria could be applied to 
determine whether the care recommended could be provided.

One might argue that there is no ultimate difference between changing the standard of care to incorporate rationing criteria and applying rationing criteria to the recommendations of a physician. Given that guidelines are being developed for use by physicians and courts to distinguish between necessary and unnecessary care, it would be practical and logical to simply build the rationing criteria into the guidelines. That may even be more efficient, because it would eliminate the step of applying rationing criteria to the recommendations of a physician. The criteria could simply be applied by the physician at the time of treatment, and applied by a court as the standard of care in the event of a malpractice case.

However, use of guidelines to be applied by physicians in the implementation of rationing would have the adverse effects already mentioned. In addition, it would tend to legitimize rationing decisions as medically valid, since they would be applied by physicians who historically have been the fiduciaries of patients. As the use of guidelines increased, it would become increasingly difficult to distinguish between the medical decisions of physicians that are based on rationing and those that were based on the needs of the patient. ${ }^{96}$ It would not only be difficult for lay persons to tell the difference; but after a time, the use of economic considerations would become so ingrained in medical practice that physicians themselves would start to lose sight of the distinction. If this occurred, valuable information about the potential of medical practice would be lost. The detrimental impact of rationing would become much less vivid, and the need to find ways to eliminate rationing would appear deceptively less urgent.

\section{CONCLUSION}

In summary, the patient-interest oriented standard of care applicable in medical malpractice litigation should not be changed to accommodate new models of rationing. Instead, the patient's interest should continue to be the focus of the standard, and should

96 See Hall, supra note 15, at 349 (summarizing the English experience in allocating scarce health care resources in which physicians "through a process of euphemization, justified treatment restrictions as an exercise of sound medical judgment"). 
serve as the foundation principle upon which guidelines to distinguish between necessary and unneeded care are built. ${ }^{97}$ We should focus our efforts on how to develop a methodology oriented around the patient's interest for drafters of guidelines to use when confronted with the hard value judgments that will need to be made in the drafting process. If rationing becomes necessary, so be it; but the criteria should be explicit and their development and application should not alter the fiduciary nature of the physician-patient relationship. The process of developing rationing criteria should be separate from the process of determining what is appropriate for the patient in light of the patient's best interests.

97 See AMERICAN MEd. Ass'N, HOUSE OF DELEgates ProceEdings: 140TH ANNUAL MEETING 121, 136 (1991). 